\title{
STAKEHOLDERS' IMPACT ON THE ENVIRONMENTAL RESPONSIBILITY: MODEL DESIGN AND TESTING
}

\author{
Rasa Smaliukienè \\ International Economics and Management Department, Vilnius Gediminas Technical University, \\ Saulètekio al.11, LT-10223VVilnius, Lithuania.E-mail: rasasmal@vv.vgtu.lt
}

Received 20 February 2007; accepted 19 April 2007

\begin{abstract}
The study is based on comparative theoretical research into the concepts of corporate social and environmental responsibilities. Multinational enterprises (MNEs) are responsive to the stakeholders' needs. Therefore, environmental business management was integrated into model of corporate social responsibility. This demonstrates that social processes influencing corporate social responsibility are of equal importance for the development of environmental responsibility. Simultaneously, this theoretical integration leads to an understanding that corporate environmental responsibility may be also introduced into other theoretical models of social responsibility, which assess impacts of stakeholders and other social influences.

The empirical research demonstrates that environmental expectations of stakeholders are different in economically different countries. In addition, the stakeholders differently see the functions of business in environmental issues. Qualitative content analysis disclosed what form of environmental responsibility is proper in countries of developed, developing and emerging economies. In developing economies, donations are demanded most of all; in emerging economies exposed to various transformations, there is a need for social investments; in developed economies full business co-operation is preferred on environmental issues. Most important environmental outcomes of MNEs, as reflected in their annual statements, demonstrate business adaptation to different stakeholders' expectations built in economically different countries.
\end{abstract}

Keywords: corporate social and environmental responsibility, multinational enterprises, stakeholders, emerging, developed, developing economy.

\section{Introduction}

Multinational enterprises (MNEs) are the part of the world that faces miscellaneous transformations on economic, ecological and social level. Global challenges such as climate change, poverty and life-disasters interlink stakeholders' attitudes with corporate responsibility and create ethical standards for the MNEs operations throughout the world [1]. At the same time every region and country is unique and brings forward unique opportunities same as problems for MNEs. Not sustainable development in the world causes diversity in interests and expectations, which need to be met according to the stakeholders' theory. The ongoing discussion by the management scholars based on empirical findings reveals the distinction between corporate responsibility in economically different regions [2]. International standards for social and environmental responsibility like the Global Reporting Initiative, OECD Guidelines for Multinational Enterprises or ISO14001 are created according to ethics perception in developed world [3], as a result, MNEs are facing problems by getting together the needs of local and international stakeholders [4].
The main goal of the research on corporate environmental responsibility is to find the preconditions for further development of the multinational business that would reduce local and international social and ecological problems. An important step in doing this is identifying the differences in stakeholder attitudes in economically different regions. To date few papers have looked at stakeholders' impact on corporate environmental responsibility employing stakeholders' theory and highlighting economical and transformational impacts. Commonly, stakeholders' theory is used in analysis of the corporate social responsibility. There, company's social obligations and efforts in dealing with issues affecting multiple stakeholders are highlighted. Therewith social attitudes and response to stakeholders create company's sensitivity to its general environment as well to its stakeholder ecological environment. Corporate environmental, same as social responsibility, is based on good will and is highly bound up with stakeholders' management. Papers that have focused on corporate environmental issues emphasizing stakeholders' attitude mostly are designed for the practice of corporate environmental accounting in different countries of the world, like Portugal [5], China [6] or Australia 
[7] otherwise dealing with the stakeholders perception about these accountings [8]. The lack of integrated approach to stakeholders' standpoint toward environmental management, same as fragmented knowledge about stakeholders' attitudes in different countries, increases the divide between corporate social and environmental responsibility and therewith creates fragmented theoretical approach to corporate responsibility.

This article focuses on the stakeholders' attitudes regarding corporate environmental responsibility in different countries and is dealing with the reflection of these attitudes in business practice. Firm's environmental strategy can be seen as a response to the pressures of different stakeholders [9]. Article argues that environmental responsibility of MNEs are fostered and permitted only in forms that befit to stakeholders attitudes. Depending on stakeholders' attitudes, corporate environmental responsibility can be developed in one of three forms: social partnership, community investment or donation. The theoretical value of the study lies in the synthesis of corporate social and environmental responsibility by integrating environmental issues management into the model of corporate social responsibility. Employing analysis of stakeholders' attitude in developed, developing and emerging economies the hypothesis about stakeholders' social impact on the corporate environmental responsibility was confirmed. This study links fragmented knowledge from different studies about stakeholders' attitude to corporate environmental responsibility into one model. From the practical standpoint the paper provides understanding about stakeholders' attitudes in economically different countries, which is important in planning environmental responsible activities in multinational business.

This study is based on comparative theoretical research into the concepts of corporate social and environmental responsibilities. Comparative approach was used to identify the variation of stakeholders' impact in economically different regions. Qualitative content analysis disclosed what form of environmental responsibility is proper in countries of developed, developing and emerging economies.

\section{Theoretical discussion}

\subsection{Recent studies on corporate environmental responsibility}

This part of the paper will take a look at the impacts disintegrating the concepts of corporate environmental responsibility from other forms of responsibility: it will identify the points of conceptual interface and theoretical possibilities of integration.

\subsection{Natural environment as a stakeholder}

The theory defines social, economic, moral and environmental forms of corporate responsibility. From the beginning, moral responsibility was integrated into the concept of corporate responsibility and approached as a basis thereof. When the question was asked as to whom business companies are responsible against, corporate social responsibility was started being analysed as a component of the stakeholders' theory. If shareholders are regarded as one of stakeholders groups, economic responsibility becomes an integral part of corporate social responsibility. There are some opinions that the natural environment is a stakeholder [10], and therefore environmental responsibility is an integral part of corporate social responsibility.

Despite some attempts, efforts have failed to integrate environmental responsibility smoothly into the extended concept of corporate social responsibility and today we have two independent concepts. This, however, raises theoretical and practical problems related to integration of this corporate environmental responsibility into the integral business management system, which already has corporate social responsibility and stakeholders' management. Hopkins deals with this problem by naming the natural environment to be one of the stakeholders [10]. Yet, Solomon named environment as a silent stakeholder that has neither a voice nor a vote in the running of business and society [11]. Natural environment is not a traditional stakeholder, which needs may be assessed and satisfied on the basis of the stakeholders' theory. It is more rational to apply the stakeholders' theory in assessment of the stakeholders' needs related to the environment where those stakeholders exist.

In the literature, we can meet a concept of corporate social and environmental responsibility, where it is attempted to combine these two notions in compromise, retaining the names of both responsibilities. Such attempts, however, scatter the subject matter of the concept: attention is given to environmental responsibility, while corporate social responsibility, which encompasses social, economic and moral forms, is left fragmentary. Within the last few decades, however, we have become increasingly aware of the links that exist between our social problems and the environment in which we live [12]. Consequently there are logical attempts to integrate environmental problems into corporate social issues management.

We can find a large number of definitions of corporate social responsibility encompassing responsibility against the natural environment. According to the EU 
Green Paper, corporate social responsibility is a concept whereby companies integrate social and environmental concerns in their business operations and in their interaction with their stakeholders on a voluntary basis [13]. According to corporate social responsibility interpretations by other official authorities, the enterprise can be viewed as a value creating entity. Consequently, environmental responsibility becomes an integral part of corporate social responsibility, and the name of 'corporate social responsibility in the context of environmental protection' is the specific one [14]. Consequently, it is not a new definition of the concept, but rather an interpretation thereof. When addressing environmental issues, 'corporate environmental responsibility' should persist as a basic definition.

\subsection{Interferences in concepts' integration}

Interpretation of the concept, however, does not eliminate factors obstructing successful integration of the mentioned concepts into oneness. In this context we can define two obstructing factors: rapid evolution of the theory of sustainable development and different environmental problems in corporate activities. Hence, the first factor preventing harmonious integration of environmental responsibility into the concept of corporate social responsibility is rapid evolution of the theory of sustainable development. One can think that this theory integrates corporate social and environmental responsibility, because it analyses even social, economic and environmental development. Yet, the theory has singled out and enlightened corporate environmental responsibility. Though the definition covers both social and environmental concerns, the latter are the most relevant when speaking about present impact on future. Research on sustainable development also makes a lot of play about integration of economic development and environment [15] in emphasising environmental responsibility or the quality of life in ecosystem [16]. There are attempts to approximate the theory of sustainable development to corporate social responsibility. Sustainable development is an attractive theory combining the problems conceived in the present society and offering solutions thereof. In further cross-purposes between scholars, concepts of social, economic and environmental development exist quite autonomously in the theory of sustainable development, where priority is in each case given to one of the concepts. This complicates creation of models and methods as well as the practice of implementation thereof.

The second factor preventing harmonious integration of corporate social and environmental responsibility is different relevance of environmental problems among different fields of business. Implementation of environ- mental initiatives usually differs for each company, or even sector, depending on a number of factors, such as the size of a company or the field of business [14]. Empirical hypothesis testing in the fields of fishing, water and power supply as well as in some other industries is focused on environmental problems and solutions thereof. While such problems as democracy, human and labour rights are paid relevantly low attention, and corporate social responsibility is less emphasised. It must be noted that in many businesses environmental protection was regarded as responsibility of government. In spite of divergence in today's corporate social and environmental responsibility, it is necessary to integrate these two concepts into oneness. This would enable creation and development of valuable theories and synergic management of corporate responsibility.

\subsection{Interface of corporate social and environmental responsibility}

The process of concepts integration is possible, because the concept of corporate social responsibility encompasses the concerns of environmental responsibility. Firstly, the practice of environmental responsibility is promoted by social motives arising in relation to corporate social responsibility. Secondly, the practice of environmental responsibility is responsive to stakeholders interests, and this responsiveness to the stakeholders' interests is a milestone in the concept of corporate social responsibility.

Social motives. Motives encouraging companies to engage in one or another activities can be divided into economic and social motives. Corporate social and environmental responsibility is built on voluntarism, while economic benefit of this initiative is rather neutral. Findings suggest that implementation of environmental or social management systems, though not impacting negatively firm's financial performance, does not render short-term profits either [17]. Despite neutral economic benefit, MNEs actively develop socially and environmentally responsible practice. There is growing perception among enterprises that sustainable economic success cannot be achieved only through maximising short-term profits, but instead through market-oriented responsible behaviour [18]. It should be further noted that both corporate social responsibility and environmental responsibility are based on good will and voluntarism, and therefore motives encouraging voluntary corporate social and environmental responsibilities are social. Roitstein divides social motives in companies into three groups: ethics as serious business; altruism humanitarian, good corporate citizenship; strategic decision-making - reduction of social and political risks, and development of market opportunities [19]. Motives 
from different groups of motives create an effect of synergy, and activities of companies become socially and environmentally responsible on different levels: from operational to strategic one.

Responsiveness to the stakeholders' needs. As it was mentioned before, an important quality in common for corporate social and environmental responsibility is the voluntary character of the initiatives the companies undertake in their denomination. This initiative first of all relates to the satisfaction of the interests of various stakeholders in order to improve their quality of life. According to Grossman, companies which engage with community gain an advantage from an enhanced capacity to be aware of and control risks associated with new or altered demands from consumers, employees and community stakeholders [20]. According to Porter, the guru of strategic management, today's companies ought to invest in corporate social responsibility as part of their business strategy to become more competitive. Corporate success depends on the local environment and appropriate infrastructure, the right types and quality of education to future employees, cooperation with local suppliers, local legislation and so on [21]. Accordingly, the extent MNEs will be able to develop the practice of corporate social and environmental responsibility, as promoted by social motives, depends not only on the company itself, but also on its stakeholders with different needs and expectations in different countries.

\subsection{Social responses and stakeholders assessment in corporate environmental responsibility model}

Application of theoretical models contributes to better understanding of the integrity of corporate social and environmental responsibility concepts. Application of theoretically based and empirically justified models integrating corporate social responsibility into the analysis of environmental responsibility would bring more consistency in the theory of corporate responsibility and would make its practice more homogeneous.
Social responsiveness in environmental issues management. The model offered by Wood [22] was chosen, where corporate social responsibility is approached as an inspiration of social responsiveness and outcome of social behaviour. This model combines previous theoretical corporate social responsibility discussion and is relevant in construction of a contemporary theory of corporate social responsibility. Basic ideas of the model are recurring in the most recent corporate social responsibility models.

Environmental responsibility is encouraged by social motives and stakeholders influence environmental responsiveness. All the mentioned closely relate to the Wood's model, defining that the principles of corporate social responsibility arise from institutional, organisational and individual principles, process of corporate social responsiveness is inspired by stakeholders' assessment. While outcome of corporate behaviour originates in corporate social policies, programs and impacts, social motives arising from institutional, organisational and individual principles encourage companies to form the principles of corporate environmental responsibility, which are thereafter transformed to the environmentally responsive process. This process takes into consideration the needs of various stakeholders where priority is given to life in harmless environment (now and in future). The impact of stakeholders or 'social license' demands [23] greatly affects formation of corporate environmental politics and programs. Here comes the outcome - environmental performance, which forms new social motives (Fig 1). In order to assess external impact on corporate environmental responsibility, we will discuss stakeholders and their assessment more widely.

Stakeholders' assessment in environmental issues management. From environmental perspectives, consumers, government agencies, the media, industry and trade associations as well as environmental groups are usually the most influential stakeholders [2]. Customers are increasingly pressuring companies to accept and

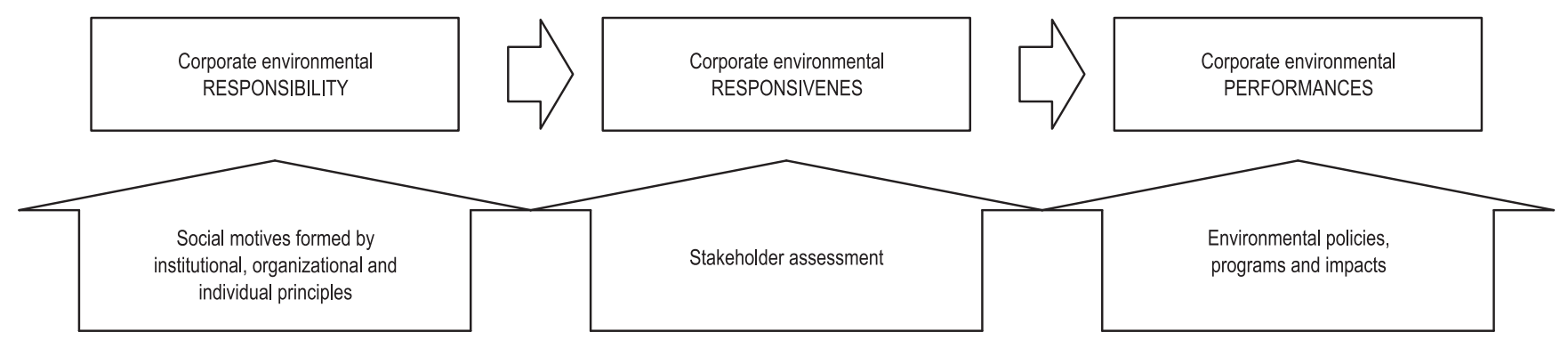

Fig 1. The conceptualisation of corporate environmental responsibility, responsiveness and performances (adopted from Wood) 
manage their responsibilities through their purchasing power [24]. The ability of the government to influence environmentally responsible business behaviour has been found to be significant, even when regulations have not been enacted [2]. Voluntary corporate environmental practice is determined by threatening new environmental regulations and seeking for a friendly attitude from government. On the other hand, "governments have a strong interest in promoting corporate social responsibility initiatives as a complement to their ongoing environmental and social programs to serve long-term national interests" [14]. The media adds to the above-discussed influences and broadens the channels of corporate social responsibility used by the stakeholders to advance corporate responsibility against society and natural environment [25]. Corporate environmental responsibility is actively facilitated by trade and industry associations. Earlier researches show that member companies of trade and industry associations are more involved into voluntary environmental initiatives, because they are under the pressure of the association [2]. Industrial associations, trade groups in particular, are interested in creation and maintenance of an environmentally positive image in order to reduce the pressure of ecologists and media representatives.

Basing on this theoretical analysis we raised the following hypothesis, which was thereafter justified by the below-described research:

H1: Responsiveness to stakeholders and their social impact impel the corporations to environmentally responsible activities.

$\mathrm{H} 2$ : Corporate environmental responsibility is possible only in such forms that are in compliance with the stakeholders'attitude.

\section{Research methods}

In order to verify the correctness of the hypotheses, we carried out a comparative research of publicly expressed expectations of stakeholders and avowed corporate environmental responsibility. A qualitative contents analysis was employed for the research. First of all, we identified stakeholders' expectations in developed, developing and emerging economies and checked the reflection of such expectations in annual corporate statements. This way we verified the first hypothesis about corporate responsiveness to stakeholders. The second stage of the research involved further analysis of the contents of the annual statements. Here we defined corporate environmental outcomes in different countries focusing on the form of outcome performance.
This served for verification of the second hypothesis about stakeholders' impact on selection of the forms of environmentally responsible activities. The two data collection processes are described below.

\subsection{Data Collection and Sample}

Sources used for the research may be divided into two big groups. The first group of sources consists of annual statements of the companies. Top 200 listed Forbes Global companies as of 2005 were chosen as initial sample for the annual survey analysis. Given the exploratory character of the study, the largest companies were chosen which are more likely to have developed a systematic response to environmental issues. The final sample of 55 companies was selected as a stratified random sample of MNEs from environmentally sensitive industries, but annual statements were available only from 43 companies $(87 \%$ ) (downloaded from web page or requested in hard copy from the individual firms).

The second group includes sources, which enlighten the standpoint of various stakeholders with regard to corporate environmental responsibility. In economically weak countries social activity of the public and consumers is low with regard to business, while the government has the major impact. Accordingly, stakeholders' expectations here were reflected only by official speeches of the leaders of the countries at the meetings of international organisations, such as UN, and declarations in English in official papers of the governments intended for international public and international business. Advocacy of international environmental organisations was approached as one more important stakeholder in economically weak countries. Official positions of these organisations were analysed as expressed in their official reports and web pages. Research of stakeholders' expectations in developed and emerging economies invoked reports of national and international environmental, consumer protection, trade unions, "aware shareholders" organisations as well as official reports and of press releases of the countries' leaders, representatives of the governments and international organisations publications within the latter three years. Only material in English was analysed, because it is easily accessible by international business community. Five model states were selected from each group of economies on the basis of the World Bank classification.

Though being attributed to one group, all information sources in the second group are very different; therefore, the method of qualitative contents analysis was applied in the research. Information sources in the first 
group are more homogeneous, but according to Krut and Munis, corporate environmental responsibility cannot be measured in figures. This would encourage creating averages and rankings, which would be inappropriate, because categories may not have equivalent value [26].

\subsection{Data Analysis}

Content analysis of stakeholder statements. We assessed environmental expectations of 38 stakeholders invoking the above-mentioned information sources. 84 documents were used in total, while distribution of these documents by the stakeholders is reflected in Table 1 . We used the qualitative contents analysis, which is a technique that enables analysis of 'open-ended' data to be structured for purposes of diagnosis [27]. It consists of a coding scheme designed for the analysis of a specific issue in question. Following this scheme, data units are identified, categorised and compared in order to reach some conclusion about the content of the communication. We applied three categories of environmental expectations of stakeholders as offered by Krut and Munis research [26]: 1) environmentally sound products, processes and services; 2) integration of sustainable development and economic growth; 3) reducing risks and hazards to human health and the ecosystem. As a basis for coding, we selected sentences that are far more reliable than any other unit of analysis. We applied a parametric method in evaluation of the extent of importance of a problem for the stakeholder (from the problem is reflected in the text content (1) to the problem is prioritised 4)) and defining the role given to business in addressing environmental problems (social partnership, community investment or philanthropy and donation).

Content analysis of the annual reports. The contents analysis of MNEs annual statements was carried out, which revealed environmental disclosure of companies. They disclose their environmental activity in various information sources, such as Internet home pages or media releases. Wilmshurst and Frost revealed legitimacy of annual reports, as that of a sole information source, in detail [28]. It is not only an easily accessible information source, but also contains attributes determining reliability of the research. Annual reports are statutory reports incorporating both statutory and voluntary disclosures. They are submitted on a regular basis and are widely recognised as the principal means of corporate communication of activities and intentions.

For the contents analysis of the annual reports the same categories were used as with regard to the stakeholders' expectation analysis. The technique for coding the units of contents was also adopted from Krut and Munis research, i.e., from "no comment on this area" to "commitment exceeds benchmark criterion". The benchmark criteria were adopted from analytical comparison study of the company codes of conduct and international standards [29]. In parallel, we analysed the form of co-operation with stakeholders selected by companies (social partnership, community investment or philanthropy and donation). A typical content coding process was applied in the research.

Table 1. Frequency of documents by stakeholders and economic development of the country

\begin{tabular}{|c|c|c|c|c|c|c|c|c|}
\hline & $\begin{array}{c}\text { Local } \\
\text { government }\end{array}$ & $\begin{array}{c}\text { Foreign } \\
\text { government }\end{array}$ & $\begin{array}{l}\text { International } \\
\text { organizations }\end{array}$ & $\begin{array}{l}\text { Consumerism } \\
\text { organizations }\end{array}$ & $\begin{array}{l}\text { Trade- } \\
\text { union }\end{array}$ & Shareholders & Environmentalists & Total \\
\hline $\begin{array}{l}\text { Developed } \\
\text { countries }\end{array}$ & 6 & - & 2 & 7 & 7 & 4 & 2 & 28 \\
\hline $\begin{array}{l}\text { Emerging } \\
\text { economy } \\
\text { countries }\end{array}$ & 9 & - & 6 & 7 & 4 & - & 2 & 28 \\
\hline $\begin{array}{l}\text { Developing } \\
\text { countries }\end{array}$ & 7 & 7 & 9 & 3 & 1 & 1 & - & 28 \\
\hline Total & 22 & 7 & 17 & 17 & 12 & 5 & 4 & 84 \\
\hline
\end{tabular}




\section{Results}

The stakeholders' environmental expectations are distributed unevenly (Table 2). Governments and international organisations are mostly interested in integration of sustained and economic development, while environmentalists and 'aware shareholders' are mainly interested in reduced risk for human health and ecosystem. The expectation of trade unions and consumer protection organisations are mainly related to environmentally sound products, processes and services.
In response to the mentioned expectations, companies build environmental policy and engage in implementation thereof in some cases exceeding the benchmark criteria (Table 3). It confirms that MNEs are sensitive to stakeholders' expectations in environmental issues. This supports the first hypothesis that responsiveness to stakeholders and their social impact impel the corporations to environmentally responsible activities.

Table 2. Stakeholders' sensitiveness to environmental issues (frequency in count and \%)

\begin{tabular}{|c|c|c|c|c|c|c|c|c|}
\hline \multirow[b]{3}{*}{ Stakeholders: } & \multicolumn{8}{|c|}{ Problems prioritised by stakeholders } \\
\hline & \multicolumn{2}{|c|}{$\mathrm{A}$} & \multicolumn{2}{|c|}{$\mathrm{B}$} & \multicolumn{2}{|c|}{$\mathrm{C}$} & \multicolumn{2}{|c|}{$\mathrm{D}$} \\
\hline & $\mathrm{N}$ & $\%$ & $\mathrm{~N}$ & $\%$ & $\mathrm{~N}$ & $\%$ & $\mathrm{~N}$ & $\%$ \\
\hline - local government, $N=22$ & 4 & 18,18 & 17 & 77,27 & 5 & 22,73 & 3 & 13,64 \\
\hline - foreign governments, $N=7$ & 2 & 28,57 & 6 & 85,71 & 1 & 14,29 & - & \\
\hline - international organisations, $N=17$ & 7 & 41,18 & 15 & 88,24 & 9 & 52,94 & 2 & 11,76 \\
\hline - environmentalists, $N=4$ & 3 & 75,00 & 2 & 50,00 & 4 & 100,00 & 2 & 50,00 \\
\hline - 'aware shareholders', $N=5$ & 2 & 40,00 & 1 & 20,00 & 5 & 100,00 & - & \\
\hline - trade unions, $N=12$ & 12 & 100,00 & 5 & 41,67 & 2 & 16,67 & - & \\
\hline - consumers' organisations, $N=17$ & 17 & 100,00 & 2 & 11,76 & 3 & 17,65 & - & \\
\hline $\begin{array}{l}\text { A - Environmentally Sound Products, } \\
\text { B - Integration of sustainable develop } \\
\text { C - Reducing risks and hazards to hu } \\
\text { D - Community/stakeholder participa }\end{array}$ & cess & nd Servi & th; & & & & & \\
\hline
\end{tabular}

Table 3. MNEs environmental disclosure (frequency in count and \%)

\begin{tabular}{|c|c|c|c|c|c|c|c|c|}
\hline & \multicolumn{8}{|c|}{ Environmental attitudes in companies annual statements, $\mathrm{N}=43$} \\
\hline & \multicolumn{2}{|c|}{ A } & \multicolumn{2}{|c|}{$\mathrm{B}$} & \multicolumn{2}{|c|}{$\mathrm{C}$} & \multicolumn{2}{|c|}{$\mathrm{D}$} \\
\hline & $\mathrm{N}$ & $\%$ & $\mathrm{~N}$ & $\%$ & $\mathrm{~N}$ & $\%$ & $\mathrm{~N}$ & $\%$ \\
\hline No comment on this area & 1 & 2,33 & 11 & 25,58 & 8 & 18,60 & 10 & 23,26 \\
\hline Issue identified/raised for consideration & 0 & 0,00 & 1 & 2,33 & 2 & 4,65 & 0 & 0,00 \\
\hline Partial commitment & 7 & 16,28 & 4 & 9,30 & 10 & 23,26 & 2 & 4,65 \\
\hline Full commitment to this issue & 20 & 46,51 & 20 & 46,51 & 24 & 55,81 & 18 & 41,86 \\
\hline $\begin{array}{l}\text { Commitment exceeds benchmark } \\
\text { criterion }\end{array}$ & 4 & 9,30 & 4 & 9,30 & 4 & 9,30 & 2 & 4,65 \\
\hline
\end{tabular}

A, B, C, D - as in previous table 
Analysis of stakeholders' expectations in relation to the role of business in environmental issues revealed a certain trend. Most stakeholders representing the interests of economically weak countries expect donations and philanthropy from business. Public-private partnership is encouraged and business is considered as a social partner only by international organisations. Emerging economies mainly expect social investments from business, while developed economies are waiting for social partnership (Table 4). Typical samples of such expectations are illustrated in Table 5. In their turn, MNEs statements show environmental outcomes in various countries, where they are distributed by stakeholders' expectations: in economically weak countries donations and philanthropy were used for most projects and environmental outcomes; in emerging economies there is more co-operation, but community investments still account for the major portion of environmental outcomes; in developed economies the biggest number of partnerships with stakeholders was revealed (Table 6). This way we support the second hypothesis that corporate environmental responsibility is possible only in such forms that are in compliance with the stakeholders'attitude.

Table 4. Stakeholders' expectations with regard to business involvement in environmental issues

\begin{tabular}{|c|c|c|c|c|c|c|c|c|c|}
\hline \multirow[b]{3}{*}{ Stakeholders, (documents $N=84$ ): } & \multicolumn{9}{|c|}{ Stakeholders' expectations expressed in documents, $\mathrm{N}$} \\
\hline & \multicolumn{3}{|c|}{ in developed countries } & \multicolumn{3}{|c|}{ in emerging countries } & \multicolumn{3}{|c|}{ in developing countries } \\
\hline & 1 & 2 & 3 & 1 & 2 & 3 & 1 & 2 & 3 \\
\hline - local government, $N=22$ & 7 & 1 & 1 & 2 & 6 & 1 & & 1 & 6 \\
\hline - foreign governments, $N=7$ & - & - & - & - & - & - & 1 & 4 & 3 \\
\hline - international organisations, $N=17$ & 10 & - & - & 2 & - & - & 12 & 4 & 4 \\
\hline - environmentalists, $N=4$ & 2 & - & 2 & - & - & - & - & 2 & - \\
\hline - 'aware shareholders', $N=5$ & - & 4 & - & - & 2 & - & - & - & 5 \\
\hline - trade unions, $N=12$ & 9 & 3 & - & 1 & - & - & 4 & - & 2 \\
\hline - consumers' organisations, $N=17$ & 5 & - & - & - & - & - & - & - & - \\
\hline
\end{tabular}

Table 5. Categorization of stakeholders' expectations

\begin{tabular}{|l|l|}
\hline $\begin{array}{c}\text { Attitudes toward } \\
\text { business participation }\end{array}$ & \multicolumn{1}{c|}{ Examples from content analysis } \\
\hline Social partnership & $\begin{array}{l}\text {..would only be possible to live up to the Millennium Development Goal for water and } \\
\text { sanitation if all actors in the sector -- national governments and local authorities, donors, civil } \\
\text { society, public operators and private sector - joined forces (UN, Commission on Sustainable } \\
\text { Development, official from Switzerland) }\end{array}$ \\
\hline $\begin{array}{l}\text { Community } \\
\text { investment }\end{array}$ & $\begin{array}{l}\text { There was also growing recognition that, even with the provision of greater budgetary } \\
\text { allocation, the States could not do it (action on water) alone. State support must be } \\
\text { complemented by local action to achieve progress on the ground (UN. 58 General Assembly, } \\
\text { official from Sierra Leone) }\end{array}$ \\
\hline Endowment & $\begin{array}{l}\text { Government hoped to increase financial resources from the private sector and to adopt } \\
\text { mechanisms for more efficient use of existing resources (water). (UN, Commission on } \\
\text { Sustainable Development, official from Colombia) }\end{array}$ \\
\hline
\end{tabular}


Table 6. MNEs commitment to environmental issues in developed, emerging and developing countries

\begin{tabular}{|c|c|c|c|c|c|c|c|c|c|c|c|c|c|}
\hline \multirow{2}{*}{$\begin{array}{l}\text { Type of } \\
\text { activity }\end{array}$} & \multirow{2}{*}{$\begin{array}{l}\text { Examples from content } \\
\text { analysis }\end{array}$} & \multicolumn{4}{|c|}{$\begin{array}{c}\text { Activities in developed } \\
\text { countries, } N=117\end{array}$} & \multicolumn{4}{|c|}{$\begin{array}{l}\text { Activities in emerging } \\
\text { countries, } N=90\end{array}$} & \multicolumn{4}{|c|}{$\begin{array}{c}\text { Activities in developing } \\
\text { c., } N=77\end{array}$} \\
\hline & & A & B & $\mathrm{C}$ & $\mathrm{D}$ & A & B & $\mathrm{C}$ & D & A & B & $\mathrm{C}$ & $\mathrm{D}$ \\
\hline $\begin{array}{l}- \text { social } \\
\text { partnership }\end{array}$ & $\begin{array}{l}\text { HMC supports the Korea's } \\
\text { eco-friendly building } \\
\text { enterprise }\end{array}$ & 8 & 12 & 37 & 14 & 6 & 2 & 9 & - & 1 & - & - & - \\
\hline $\begin{array}{r}\text { - community } \\
\text { investment }\end{array}$ & $\begin{array}{l}\text { Reforestation project in } \\
\text { Peru has converted arid land } \\
\text { into forest and "generated } \\
\text { more than } 120 \text { jobs for local } \\
\text { people during the installation } \\
\text { of the irrigation system } \\
\text { and planting of trees, }<\ldots> \\
\text { also provided a green area } \\
\text { for research, transfer of } \\
\text { knowledge and recreation }\end{array}$ & 5 & 2 & 15 & 1 & 22 & 9 & 13 & 11 & 12 & - & 8 & - \\
\hline - endowment & $\begin{array}{l}\text { Donation by Environmental } \\
\text { Investment Programme in } \\
\text { Georgia that supports local } \\
\text { initiatives focused on the } \\
\text { promotion and conservation } \\
\text { of biodiversity }\end{array}$ & 6 & - & 17 & - & - & 1 & 12 & 5 & 32 & - & 24 & - \\
\hline
\end{tabular}

\section{Conclusions and discussion}

Stakeholders promote and allow only such forms of corporate environmental responsibility that are compatible with their attitude towards business. MNEs are sensitive to social influences and thus, in response, select the forms of environmental responsibility that are most of all acceptable for the stakeholders.

Our research disclosed the importance of social influences on corporate environmental responsibility and enlightened the significance of stakeholders' expectations in organisation of environmental activities. The empirical research demonstrated that environmental expectations of stakeholders are different in economically different countries. In addition, the stakeholders differently see the functions of business in environmental issues. In developing economies, donations are demanded most of all; in emerging economies exposed to various transformations, there is a need for social investments; in developed economies full business cooperation is preferred on environmental issues. Most important environmental outcomes of MNEs, as reflected in their annual statements, demonstrate business adaptation to different stakeholders' expectations built in economically different countries.
The research does not negate that environmental responsibility arises from internal corporate responsibility as it was proved by other studies. Yet, it proves that the stakeholders are highly influential in MNEs selection of environmentally responsible activities. Assessment of the stakeholders' impact rendered a value of practical applications for the research. In the theoretical discussion Gago and Antolin say that the natural environment has become an element of great importance in corporate social action, and stakeholders' theory has been fundamental in achieving a more practical view [9]. The results of the study confirm and extend the conclusions of recent research conducted on corporate environmental responsibility. A number of studies have proved that the pressures of stakeholders influence environmental management practices [6], while our research adds support that the stakeholders' pressure varies subject to national economies and transformations taking place in the countries.

MNEs are responsive to the stakeholders' needs. Therefore, we integrated environmental business management into Wood's model of corporate social responsibility. This enabled us to demonstrate that social processes influencing corporate social responsibility are of equal importance for the development of envi- 
ronmental responsibility. Simultaneously, this theoretical integration leads to an understanding that corporate environmental responsibility may be also introduced into other theoretical models of social responsibility, which assess impacts of stakeholders and other social influences. Changing public awareness of environmental protection entails variation in the concept of "social". Theories introduce more and more new criteria and references defining the broadness of the concept of "social" and thus express the level of corporate and public relations on which the stakeholders' interests are being satisfied. Safe environment, which has become one of the most important interest of the stakeholders, promote corporate environmental responsibility.

The results of the present study open new directions for future investigation. Globalisation lifts strict boundaries within which MNEs should act in economically different countries. Therefore, in future studies it would be reasonable to go deeper into the influence of international community on corporate responsibility. On the other hand, each region of the world has its identity and influence of stakeholders acting therein is unique. Accordingly, regional analysis of stakeholders' expectations would extend and specify the results of this research in more details. This research presents a consequence when the level of economic development in a country forms certain attitudes of stakeholders, while dynamics in the stakeholders' expectations in line with changing economic status of the country open new directions for future research.

\section{References}

1. CARROLL, A. B. Managing ethically with global stakeholders: A present and future challenge. Academy of Management Executive, 2004, 18 (2): 114-120.

2. RIVERA, J. Institutional pressures and voluntary environmental behavior in developing countries: Evidence from the Costa Rican hotel industry. Society \& Natural Resources, 2004, 17 (9): 779-797.

3. RAINES, S. S. Perceptions of legitimacy and efficacy in international environmental management standards: The impact of the participation gap. Global Environmental Politics, 2003, 3 (3): 47-73.

4. EGELS, N. CSR in electrification of rural Africa. Journal of Corporate Citizenship, 2005, 18: 75-85.

5. FERREIRA, C. Environmental accounting: the Portuguese case. Management of Environmental Quality: An International Journal, 2004, 6 (15): 561-573.

6. WONG, L. T.; FRYXELL, G. E. Stakeholder influences on environmental management practices: A study of fleet operations in Hong Kong (SAR), China. Transportation Journal, 2004, 43 (4): 22-35.

7. DEEGAN, C.; RANKIN, M. Do Australian companies report environmental news objectively? Auditing \& Accountability Journal, 1996, 2 (9): 50-67.

8. FAULKNER, D.; CARLISLE, Y. M.; VINEY, H. P. Changing corporate attitudes towards environmental policy. Management of Environmental Quality: An International Journal, 2005, 16 (5): 476-489.

9. GAGO, R. F.; ANTOLIN, M. N. Stakeholders salence in corporate environmental strategy. Corporate Governance, 2004, 4 (3): 65-76.

10. HOPKINS, M. Corporate social responsibility: an issues paper. Policy World Commission on the Social Dimension of Globalization. International Labour Office, Geneva, Working Paper 27, 2004.

11. SOLOMON, R. C. Above the bottom line - an introduction to business ethics. Harcourt Brace, Fort Worth, TX, 1994.

12. HOUSER, N. O. Inquiry Island: Social responsibility and ecological sustainability in the twenty-first century. The Social Studies, 1996, 3: 127-132.

13. Commission of the European Communities. Green Paper. Promoting a European Framework for Corporate Social Responsibility. Brussels, 2001.

14. MAZURKIEWICZ, P. Corporate environmental responsibility: Is a common CSR framework possible? World Bank. Available from Internet: <http://siteresources. worldbank.org/EXTDEVCOMSUSDEVT/Resources/ csrframework.pdf.>

15. HILSON, G.; BASU, A. J. Devising indicators of sustainable development for the mining and minerals industry. International Journal for Sustainable Development \& World Ecology, 2003, 10 (4): 319-331.

16. MARTEN, G. G. Human ecology: Basic concepts for sustainable development. Sterling, VA: Earthscan Publications Ltd, 2001.

17. WATSON, K.; KLINGENBERG, B.; POLITO, T.; GEURTS, T. G. Impact of environmental management system implementation on financial performance. A comparison of two corporate strategies. Management of Environmental Quality: An International Journal, 2004, 15 (6): 622-628.

18. Commission of the European Communities. Corporate social responsibility: A business contribution to sustainable development. Brussels, 2002.

19. ROITSTEIN, F. Analysis of corporate social responsibility training initiatives in multinational enterprises: The challenge of localizing CSR. World Bank, 2005. Available from Internet: <http://siteresources.worldbank. org/.../20385474/AnalysisCSRTrainingFINAL.pdf.> 
20. GROSSMAN, H. A. Refining the role of the corporation: The impact of corporate social responsibility on shareholder primacy theory. Deakin Law Review, 2005, 10 (2): 572-596.

21. PORTER, M. CSR - a religion with too many priests? European Business Forum, 15, Copenhagen Business School, September, 2003.

22. WOOD, D. J. Social issues in management: Theory and research in corporate social performance. Journal of Management, 1991, 17(2): 383-406.

23. THORNTON, D.; KAGAN, R. A.; GUNNINGHAM, N. Sources of corporate environmental performance. California Management Review, 2003, 46 (1): 127-141.

24. WADDOCK, S. A.; BODWELL, C.; GRAVES, S. B. Responsibility: The new business imperative. Academy of Management Executive, 2002, 16 (2): 132-148.

25. RARE: Rhetoric and realities: analyzing corporate social responsibility in Europe. A research Project within the
EU's Sixth Framework Programme. Berlin, 2005. Available from Internet: <www.rare-eu.net $>$

26. KRUT, R.; MUNIS, K. Sustainable industrial development: Benchmarking environmental policies and reports. Greener Management International, 1998, 21: 87-98.

27. MILNE, M. J.; ADLER, M. W. Exploring the reliability of social and environmental disclosures content analysis. Accounting, Auditing and Accountability Journal, 1999, 12 (2): 237-256.

28. WILMSHURST, T. D.; FROST, G. R. Corporate environmental reporting. A test of legitimacy theory. Accounting Auditing \& Accountability Journal, 2000, 13 (1): 10-26.

29. SMITH, G.; FELDMAN, D. A. Company codes of conduct and international standards: An analytical comparison. The World Bank Group. Corporate Social Responsibility Practice. 2003. Available from Internet: <http://siteresources.worldbank.org/ INTPSD/.../CSR/CompanyCodesofConductII.pdf.> 